\title{
Involvement of BDNF in age-dependent alterations in the hippocampus
}

\section{Oliver von Bohlen und Halbach*}

Institute for Anatomy and Cell Biology, Ernst Moritz Arndt University of Greifswald, Greifswald, Germany

\section{Edited by:}

Jesus Avila, Centro de Biología

Molecular Severo Ochoa Consejo

Superior de Investigaciones Científicos

Universidad Autonoma De Madrid,

Spain

Reviewed by:

Ricardo Insausti, University of

Castilla-La Mancha, Spain

Marina P. Sanchez, Fundacion Jimenez

Diaz/Clinica Ntra Sra Concepcion, Spain

\section{*Correspondence:}

Oliver von Bohlen und Halbach,

Institute of Anatomy and Cell Biology,

Ernst Moritz Arndt University of

Greifswald, Friedrich Loeffler Strasse

23c, 17487 Greifswald, Germany.

e-mail: oliver.vonbohlen@arcor.de
It is known since a long time that the hippocampus is sensitive to aging. Thus, there is a reduction in the hippocampal volume during aging. This age-related volume reduction is paralleled by behavioral and functional deficits in hippocampus-dependent learning and memory tasks. This age-related volume reduction of the hippocampus is not a consequence of an age-related loss of hippocampal neurons. The morphological changes associated with aging include reductions in the branching pattern of dendrites, as well as reductions in spine densities, reductions in the densities of fibers projecting into the hippocampus as well as declines in the rate of neurogenesis. It is very unlikely that a single factor or a single class of molecules is responsible for all these age-related morphological changes in the hippocampus. Nevertheless, it would be of advantage to identify possible neuromodulators or neuropeptides that may contribute to these age-related changes. In this context, growth factors may play an important role in the maintenance of the postnatal hippocampal architecture. In this review it is hypothesized that brain-derived neurotrophic factor (BDNF) is a factor critically involved in the regulation of age-related processes in the hippocampus. Moreover, evidences suggest that disturbances in the BDNF-system also affect hippocampal dysfunctions, as e.g. seen in major depression or in Alzheimer disease.

Keywords: aging, hippocampus, brain-derived neurotrophic factor, depression, dendritic spines, neurogenesis

\section{THE AGED HIPPOCAMPUS}

The hippocampal formation, a brain structure involved in spatial memory, exhibits marked functional decline with aging in humans, monkeys, and rodents (Greene and Naranjo, 1987; Walker et al., 1988; Lee et al., 1994; Rapp and Heindel, 1994; Rapp and Gallagher, 1996; Driscoll et al., 2003). Since a long time it is well established that there is a reduction in the hippocampal volume during aging in healthy adults (Figure 1). Several studies, using e.g. magnetic resonance imaging (MRI), confirmed the age-related reduction in hippocampal volume (Convit et al., 1995; Mu et al., 1999; Driscoll et al., 2003; Malykhin et al., 2008; Raz et al., 2010). This age-dependant shrinkage of the hippocampus was found to be accelerated with time (Raz et al., 2010; Zhang et al., 2010). Age-related deficits could e.g. be observed in the performance on hippocampus-dependent tasks in humans and it has been shown that these deficits were accompanied by decreased hippocampal volume (Driscoll et al., 2003). This hippocampal shrinkage has been attributed to hippocampal atrophy and to neuronal losses or decreases in neuronal densities (Driscoll et al., 2003). In early morphometric studies that determined the number of human hippocampal neurons directly, it was found that normal aging was accompanied by a more or less pronounced gradual loss of hippocampal neurones (Ball, 1977; Mani et al., 1986). These as well as other results suggest that the hippocampus undergoes structural and biochemical changes during normal aging.

These alterations in the hippocampus during aging are paralleled by behavioral and functional deficits in hippocampusdependent learning and memory tasks (Rosenzweig and Barnes, 2003). The hippocampus is involved, e.g. in spatial learning tasks and both, aged humans and aged rodents exhibit spatial memory deficits (Barnes, 1987). In rodents, age-related impairments have been described for hippocampus-dependant spatial as well as for contextual learning tasks, such as water maze and fear conditioning (Ward et al., 1999; Rosenzweig and Barnes, 2003). Moreover, it has been shown that learning deficits in aged rats are accompanied by a decrease in hippocampal volume (Sykova et al., 2002).

Spatial navigation is a complex cognitive skill that involves the hippocampus of humans and it is known that navigation, as an aspect of cognitive function, is vulnerable to aging (Moffat, 2009). In this context, it is important to note that older individuals required more time to form a cognitive map of the environment than young individuals (Iaria et al., 2009). In addition, way-finding has been associated with the hippocampus and also for way-finding it has been shown that aging effects recall of landmarks, and the recognition of environmental scenes (Head and Isom 2010). Interestingly, the age-related changes in way-finding were significantly associated with hippocampal volume changes (Head and Isom 2010).

Thus, it can be concluded that aging is often accompanied by hippocampal-dependent learning and memory problems, many of which resemble deficits associated with hippocampal damage. Despite such evidences that age-related dysfunctions are associated with reductions in the volume of the hippocampal formation, the cellular and morphological basis of this decline is largely unknown.

\section{ALTERATIONS IN THE INNERVATION OF THE AGED HIPPOCAMPUS}

Since there is an association between hippocampal volume reductions and declines in hippocampus dependent learning and memory function, other structural changes may be related to the dysfunction 


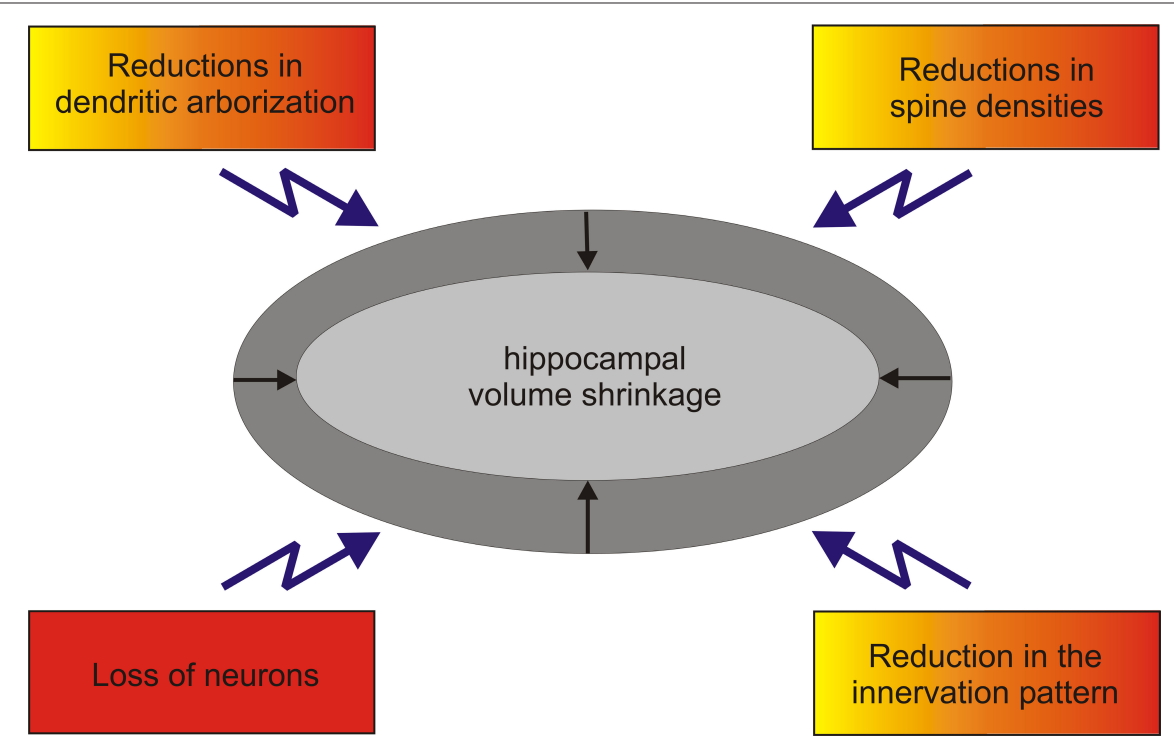

FIGURE 1 | Hippocampal volume reduction is the sum of different morphological changes. Volume shrinkage seen during normal aging (yellow) or in major depression (orange) is not due to a severe loss of hippocampal neurons. Hippocampal volume reduction together with severe losses of hippocampal neurons could e.g. bee seen in Alzheimer's disease (red).

of the aged hippocampus. The analysis of the aged hippocampus revealed indeed several structural changes that may be associated with reductions in the hippocampal volume.

During aging, there is e.g. an increase in the density of fragments of degenerated axons within the hippocampus (von Bohlen und Halbach and Unsicker, 2002). This increased density of degenerated fibers is indicative for a loss of fibers within the aged hippocampus. Thus, a reduction in fibers projecting into the aged hippocampus may contribute to the volume reductions in the aged hippocampus. The hippocampal formation is innervated by cortical and subcortical areas; however, within the aged forebrain, cell losses in cortical areas that project to the hippocampus, as e.g. the entorhinal cortex, seem not to represent a hallmark of aging (Gazzaley et al., 1997; Merrill et al., 2001).

The noradrenergic system projects into the hippocampal formation. The source for these fibers is located in the locus coeruleus (Robinson et al., 1977; Ader et al., 1980). Data concerning a possible loss of neurons within the locus coeruleus are not consistent; thus, no cell loss as well as cell losses in that nucleus have been reported in the context of aging (Lohr and Jeste, 1988; Chan-Palay and Asan, 1989; Manaye et al., 1995; Ohm et al., 1997). Nevertheless, there is evidence to suggest that there is a decline in the density of noradrenergic fibers innervating the aged dentate gyrus (DG) (Ishida et al., 2000). A further system that projects into the hippocampus is the dopaminergic (DAergic) system. Concerning the DAergic system and the hippocampus, it is known that the hippocampus is innervated by DAergic neurons, located in the ventral tegmental area and the substantia nigra (Gasbarri et al., 1994). This DAergic mesolimbic system is sensitive to aging (Miguez et al., 1999) and might be implicated in age-related impairments (Barili et al., 1998). Indeed, the total number of DAergic neurons in the substantia nigra decreases with age (Naoi and Maruyama, 1999; Siddiqi et al., 1999). Based on that, it may be possible that there is an age-related loss of DAergic fibers within the hippocampus. One enzyme, tyrosine-hydroxylase ( $\mathrm{TH})$ is involved in the biosynthesis of both, dopamine and noradrenalin. TH is located not only in the soma, but also in the processes of DAergic and noradrenergic neurons. Using TH-immunohistochemistry, it has been shown that there is an age-related decline in the density of TH-positive fivers within the DG (von Bohlen und Halbach and Unsicker, 2003). Along this line, it has been shown that aged rats display reduced concentration of dopamine and noradrenalin in the hippocampus (Miguez et al., 1999).

Serotonin, another transmitter, is also produced in areas that are sensitive to aging. For example, it has been shown that the numbers of serotonergic neurons within different raphe nuclei of rats decrease during aging (Tatton et al., 1991; Lolova and Davidoff, 1992). This age-related cell loss might be responsible for the marked decrease in the density of serotonergic fibers within the DG (Nishimura et al., 1995).

Furthermore, the hippocampus is also innervated by cholinergic fibers that stem from the septum. These septo-hippocampal projections are e.g. involved in the modulation of short-term spatial (working) memory processes (Everitt and Robbins, 1997). Whereas the number and size of cholinergic neurons within the septum is not altered in the context of aging (Ypsilanti et al., 2008; Niewiadomska et al., 2009), there is a marked decrease in cholinergic fibers projecting into the hippocampus (Gilad et al., 1987; Ypsilanti et al., 2008; Niewiadomska et al., 2009), indicating that cholinergic axonal degeneration occurs during aging.

Thus, axonal degeneration in the hippocampus is likely to be due to reductions in the amount of fibers that supply the hippocampus with different transmitters. The loss of these fibers could contribute to hippocampal dysfunctions and may contribute to volume losses of the aged hippocampus. 


\section{NEUROGENESIS AND THE AGED HIPPOCAMPUS}

Neurogenesis has long been believed only to occur during brain development. However, in some areas within the forebrain, namely the subventricular zone and the DG, neurogenesis persists in the postnatal brain. The rate of neurogenesis within the DG can be altered under various physiological and pathophysiological conditions. Interestingly, neurogenesis within the DG seems to be linked to hippocampus-dependent learning and memory.

Neurogenesis within the DG is increase in mice that were housed in an enriched environment (Kempermann et al., 1997). Increased neurogenesis within the DG is also observed in a variety of hippocampusdependent learning and memory tasks (Drapeau et al., 2003; Ming and Song, 2005; Snyder et al., 2005). Furthermore, enriched environment not only increases neurogenesis in the DG, but also improves spatial memory (Nilsson et al., 1999). Thus, functional neurogenesis seems to have a profound impact upon neuronal plasticity within the hippocampus. Along this line, it has also been shown that long-term potentiation (LTP), a well characterized form of synaptic plasticity believed to play a critical role in memory formation, stimulates neurogenesis within the hippocampus (Bruel-Jungerman et al., 2006).

Since the hippocampus exhibits marked functional decline with aging, it could be speculated that neurogenesis within the aged DG is altered. Indeed, it has been shown that neurogenesis is drastically reduced in aged animals (e.g. rats Kuhn et al., 1996 and monkeys Gould et al., 1999). Neurogenesis therefore seems to be linked to hippocampal functions and an age-related decline in hippocampal functions seems to be accompanied by a reduction in neurogenesis. Given that neurogenesis occurs throughout the postnatal life, one would expect that the DG would increase in size during adulthood and that therefore the number of granule cells is increased in aged animals as compared to adult animals. However, this is not the case. Granule cell number of the DG do not increase with age (Rapp and Gallagher, 1996; Rasmussen et al., 1996; von Bohlen und Halbach and Unsicker, 2002), indicating that proliferation is balanced by cell death. Thus, not the addition of new neurons into the DG seemed to be linked to hippocampal functions, but the rate of the turnover of granule cells within the DG. Based on that, the reduced rate of neurogenesis within the aged DG seems not to contribute to volume reductions in the aged hippocampus.

\section{AGE-RELATED CHANGES IN THE MORPHOLOGY OF NEURONS IN THE AGED HIPPOCAMPUS}

Aside from age-related changes in the innervation pattern of the hippocampus, other structural changes may contribute to the volume reductions seen in the aged hippocampus. These structural changes may be related to the number of neurons within the aged hippocampus (see "Age-related changes in neuronal numbers in the aged hippocampus") or may be associated directly with the neurons located in the aged hippocampus. Structural changes of individual neurons in the aged hippocampus could e.g. be observed in altered branching patterns of neurons.

Concerning the DG, it has been described that volume fraction and surface area of dendritic shaft profiles are significantly decreased in senescent rats, relative to young adults (Geinisman et al., 1978) as well as the number of synapses (Bondareff, 1979). A morphometric analyses showed that cells from aged monkeys had significantly reduced vertical dendritic extents and distal dendritic branching, but increased proximal dendritic branching. However, the total dendritic length, number of dendritic branch points, and total segment number did not differ significantly from cells in the DG of young monkeys (Luebke and Rosene, 2003).

Concerning area CA1 of the hippocampus, a marked age-related reduction (nearly 40\%) in the dendritic branch profiles (located in the stratum lacunosum-moleculare) of CA1 pyramidal neurons has been found that is accompanied by a marked decrease in the total volume fraction and total surface of dendrites per volume neuropil (Lolova, 1989). Somewhat comparable to the results obtained for area CA1, neurons located in subiculum also show reductions in their dendritic complexity (Uemura, 1985).

The dendrites of the hippocampal pyramidal and granular neurons are covered by small protrusions known as dendritic spines. Dendritic spines - at least in area CA1 - are the predominant site of excitatory synapses in the hippocampus (Megias et al., 2001). The density of dendritic spines is related to the amount of connectivity between the neurons with the dendritic spines and the axons from other neurons that built up synaptic contacts (von Bohlen und Halbach, 2009). One role of the dendritic spines is to establish and to maintain these connections. In addition, these small structures seem also to be involved in other functions, since they compartmentalize calcium and other signaling components that are involved in synaptic efficacy (Fiala et al., 2002). Thus, it is not surprisingly that dendritic spines are thought to play a role in neuronal plasticity. Indeed, some forms of learning have been shown to increase the number of dendritic spines (Geinisman, 2000; Yuste and Bonhoeffer, 2001; Nimchinsky et al., 2002; Leuner et al., 2003).

It is thought that the spine densities reflect the excitatory input density (Konur et al., 2003), since some forms of learning as well as hippocampal LTP have been associated with increased spine densities in the hippocampus (Engert and Bonhoeffer, 1999; Muller et al., 2000; Leuner and Shors, 2004). Moreover, LTP has been shown to promote the formation of new, mature, and probably functional synapses (Toni et al., 1999).

Thus, it may be speculated that dendritic spines might be altered in the time-course of aging in the whole hippocampus or within specific hippocampal sub-regions. No difference in spine densities have been detected within the DG of aged rats (Curcio and Hinds, 1983) as well as no changes in spine densities have been found in apical dendrites of CA1 neurons in aged rats (Lolova et al., 1989; Markham et al., 2005). Likewise, no age-related changes have been observed in spine densities of dendrites of the DG or of apical dendrites of area CA1 in mice (von Bohlen und Halbach et al., 2006b, 2008). In contrast, age-related reductions in spine numbers of hippocampal CA1 neurons have been noted by comparing senescence-accelerated mice (SAMP1TA/Ngs) at an age of 5 and 7 months (Kawaguchi et al., 1995). By comparing young adult (3-months-old) and aged (27-month-old) rats, spine densities of both basal and apical dendrites of CA1 have been found to be decreased in the old rats (Nunzi et al., 1987). Concerning mice, it has been shown that there is an age-related impairment in spatial learning as well as a decrease in the densities of basal dendrites of area CA1 (von Bohlen und Halbach et al., 2006b). In this context it is of interest to note that basal dendrites of area CA1 display an increase in spine densities, e.g. after spatial learning in rats (Moser et al., 1994). The observed age-related changes in dendritic spines may contribute to age-related impairments in synaptic plasticity, 
including deficits in LTP. These alterations may impair the encoding of memories and thus may contribute to cognitive deficits observed in aged mammals (Rosenzweig and Barnes, 2003). Altered synaptic plasticity may also change the dynamic interactions among cells in hippocampal networks, causing deficits in the storage and retrieval of information about the spatial organization of the environment (Rosenzweig and Barnes, 2003). Thus, loss of dendritic spines during normal aging mainly occurs in area CA1, but nevertheless has a profound effect upon neuronal plasticity and seems to represent a morphological correlate of age-dependent declines in neuronal plasticity and hippocampus-dependent functions.

\section{AGE-RELATED CHANGES IN NEURONAL NUMBERS IN THE AGED HIPPOCAMPUS}

Loss of neurons in the forebrain has been widely viewed as a hallmark of normal aging (Landfield et al., 1992). Indeed, early morphometric studies provided evidence that normal aging is accompanied by a more or less pronounced gradual loss of hippocampal neurons (Ball, 1977; Mani et al., 1986). However, cell counting and estimation of neuronal densities is not trivial, sinceamong others - cutting artifacts, tissue artifacts, and other factors could bias the results. The development of unbiased stereological counting rules (Sterio, 1984; Gundersen et al., 1999; West, 1999) has enabled scientists to estimate neuronal numbers more precisely. By using stereological counting rules, no significant cell losses in the DG or in the pyramidal layers of the hippocampal areas CA1-CA3 have been detected (West, 1993; Rapp and Gallagher, 1996; Rasmussen et al., 1996; Calhoun et al., 1998; von Bohlen und Halbach and Unsicker, 2002). Thus, cell loss in the hippocampal formation seems not to represent the cellular basis for volume shrinkage of the aged hippocampal formation.

In summary, volume reduction of the aged hippocampus is not an event that can be attributed to a single parameter. Instead, volume reductions seem to be the sum of different morphological changes (reduction in the innervation pattern of the hippocampus; changes in the branching pattern of distinct neuronal populations within the hippocampus; reduction of spine densities) that all contribute to the hippocampal volume reduction in the context of aging.

It is very unlikely that a single factor or a single class of effector molecules is responsible for all these age-related morphological changes in the hippocampus. Nevertheless, it would be of advantage to identify possible neuromodulators or neuropeptides that may contribute to these age-related changes. Such a substance should meet at least some of the following requirements:

1) its expression should be altered in the context of aging

2) it should influence directly hippocampal neurons (branching patterns and/or dendritic spines of hippocampal neurons)

3) it should have an impact upon transmitter systems projecting to the hippocampal formation

4) it should have an impact upon neuronal plasticity

5) it should have an impact upon hippocampal volume

In this context, a family of trophic factors can be of interest, since this family of neuropeptides meets several of these criteria. Growth factors not only play a role during development, but several of them are also expressed in the postnatal brain, along with their cognate receptors. These factors, as e.g. the neurotrophins are involved in the maintenance of the architecture of the postnatal brain as well as they play a role in neuronal plasticity.

\section{BRAIN-DERIVED NEUROTROPHIC FACTOR (BDNF)}

The family of neurotrophins consists of nerve growth factor (NGF), brain-derived neurotrophic factor (BDNF), neurotrophin 3 (NT3), and neurotrophin 4 (NT4). The neurotrophins bind to specific receptors that belong to the class of the Trk family of tyrosine protein kinase receptors. NGF specifically recognizes trkA, whereas BDNF and NT4 specifically activate trkB receptors. NT3, finally, primarily activates trkC receptors (Figure 2 ). In addition, all the neurotrophins can signal through a low-affinity receptor (which is structurally unrelated to the trk receptors), known as p75 receptor (Barbacid, 1994; Teng and Hempstead, 2004). In the context of age-related structural changes within the hippocampus, BDNF and its receptors may be of particular interest.

\section{AGE-RELATED EXPRESSION OF BDNF}

Levels of BDNF are not constant during the postnatal period. However, whether BDNF is up- or down-regulated in the context of aging seems to be region-dependent and species specific. It has been described that BDNF increases in the murine hippocampus during normal aging, but not during aging of mice with pathological changes (Katoh-Semba et al., 1998), whereas in aged rats a decline in hippocampal BDNF levels, as compared to young adult rats, has been observed (Karege et al., 2002). In aged monkeys (26, 30 , and 32 years), the intensity of BDNF-immunoreactivity has been found to decline in cell bodies and dendrites of the neurons in the hippocampal formation (Hayashi et al., 2001). In humans, BDNF levels in plasma have been found to decrease with increasing age (Lommatzsch et al., 2005), but within the human hippocampus, levels of BDNF mRNA seem not to change significantly with

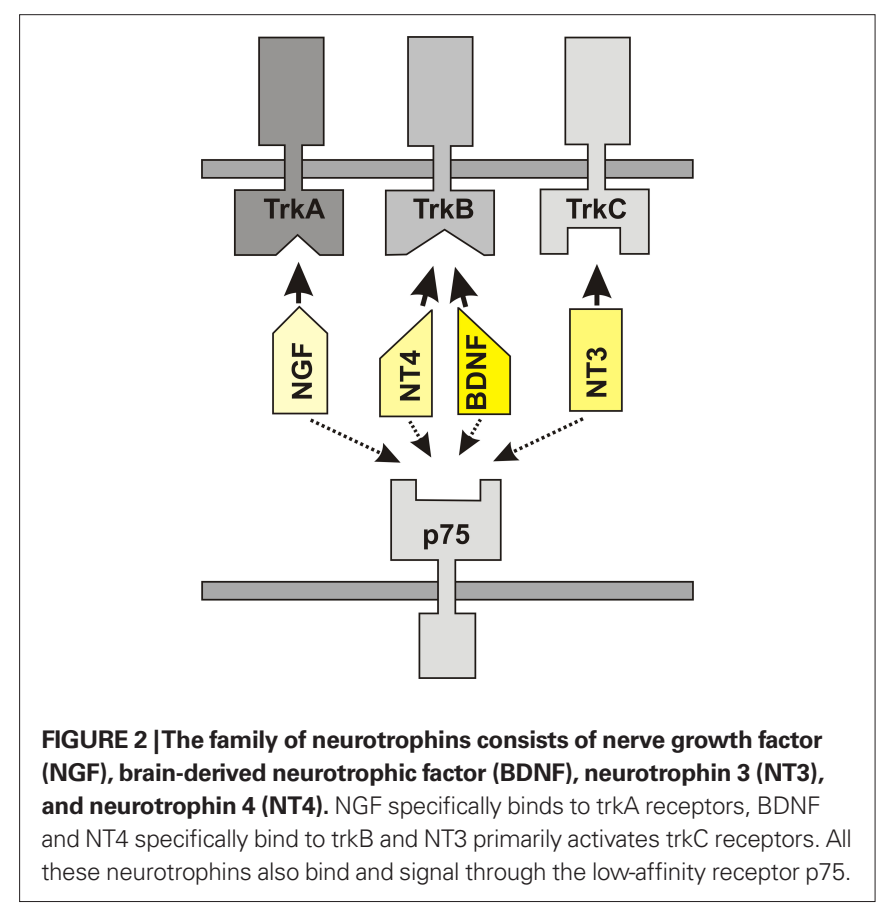


age (Webster et al., 2006), but the levels of trkB mRNA decreased over the life span (Webster et al., 2006). In accordance with these results, it has been shown that the levels of trkB decrease in the rat hippocampus during aging (Croll et al., 1998; Silhol et al., 2005). In summary, there is evidence that suggest that the BDNF-trkB system in the hippocampus is sensitive to aging.

\section{BDNF AND ITS IMPACT UPON NEURONAL MORPHOLOGY}

Transfection of granule cells from the DG with BDNF produces significant increases in axonal branch and basal dendrite numbers relative to empty vector controls. In addition, it has been shown by the same group that these structural changes could be prevented by the tyrosine kinase inhibitor K252a (Danzer et al., 2002). Thus, an increased expression of BDNF is sufficient to induce these morphological changes and it is likely that these morphological alterations are induced by an activation of trkB receptors. Results obtained by using mice that over-express BDNF confirmed these observations, since an increase in the dendrite complexity of DG cells could be observed in these mice (Tolwani et al., 2002).

BDNF, however, has not only an impact upon the branching pattern of hippocampal neurons. It has been demonstrated that BDNF is capable of increasing spine density in apical dendrites of CA1 neurons in slice cultures (Tyler and Pozzo-Miller, 2003; Alonso et al., 2004). Conditional trkB-deficient mice display a reduction in spine densities within the hippocampus (von Bohlen und Halbach et al., 2006a), indicating that BDNF-trkB signaling plays a critical role in the maintenance of dendritic spines within the hippocampus. In heterozygous trkB-deficient mice, a reduction in dendritic spines has also been noted (but to a lower extent) and - in addition - there is a further reduction in dendritic spine densities in aged heterozygous trkB mice (von Bohlen und Halbach et al., 2008). Therefore, BDNF via its action through trkB receptors has profound effects upon the morphology of hippocampal neurons.

\section{DOES BDNF INFLUENCE TRANSMITTER-SYSTEMS PROJECTING TOWARDS THE HIPPOCAMPUS?}

BDNF, acting through trkB receptors, is known to enhance growth and survival of serotonergic neurons (Galter and Unsicker, 2000; Mattson et al., 2004). In the adult rat brain, BDNF is able to promote regenerative sprouting of serotonergic fibers, but not the survival of injured serotonergic axons (Mamounas et al., 2000). In aged heterozygous $\mathrm{BDNF}^{+/-}$mice the age-related loss of serotonin axons in the hippocampus was potentiated as compared to age-matched wild-type mice (Luellen et al., 2007), indicating that BDNF may play a role in the maintenance of the serotonergic system.

The noradrenergic system is also sensitive to aging. Exogenous BDNF infusion in rats caused a marked increase in the density of noradrenergic axons in the aged frontal cortex, whereas no trophic action of BDNF was observed in young and middle-aged brains (Matsunaga et al., 2004). Neutralization of endogenous BDNF with specific antibody to BDNF led to a reduction in noradrenergic axons in the frontal cortex of aged rats (Matsunaga et al., 2004). Furthermore, it has been shown that aged $\mathrm{BDNF}^{+-}$mice showed reduced numbers of cell bodies and fibers in the locus coeruleus compared with age-matched wild-type mice (Luellen et al., 2007).
These data, as well as others (Matsunaga et al., 2004, 2006; Traver et al., 2006) suggest that BDNF is necessary for the maintenance of noradrenergic innervations in the aged brain.

BDNF is also known as a neurotrophic factor for DAergic neurons of the substantia nigra (Hyman et al., 1991; Hagg, 1998; Dluzen et al., 1999). Inhibition of BDNF expression (Porritt et al., 2005) as well as a reduction of trkB expression (Zaman et al., 2004) can cause a loss of nigral DAergic neurons. The DAergic system is also sensitive to aging; thus, there is a reduction in the number of DAergic neurons during aging. This age-related cell loss is increased in aged heterozygous trkB mutant mice (von Bohlen und Halbach et al., 2005).

BDNF can promote the survival of developing cholinergic forebrain neurons and is able to attenuate the loss of neurons following excitotoxic lesions (Burke et al., 1994). Concerning the cholinergic innervation of the hippocampus, it has been shown that young $\mathrm{BDNF}^{-/-}$mice have a reduced cholinergic innervation as compared to age-matched controls (Ward and Hagg, 2000) as well as reduced numbers of cholinergic cells in the medial septum that is accompanied by a decrease in the activity of choline acetyltransferase in the hippocampus (Grosse et al., 2005). Comparable to these results, it also has been shown that mice with reduced BDNF expression display decreased choline acetyltransferase activity (Chourbaji et al., 2004).

Thus, BDNF is capable of influencing the transmitter systems projecting towards the hippocampus.

\section{BDNF IS INVOLVED IN HIPPOCAMPAL NEURONAL PLASTICITY}

BDNF at low nanomolar range exited neurons in the cerebellum, cortex and hippocampus as rapidly as the neurotransmitter glutamate (Kafitz et al., 1999). Moreover, application of BDNF produces a sustained enhancement of synaptic strength at Schaffer collateralCA1 synapses and this enhancement can be blocked by K252a (Kang and Schuman, 1995). The induction of LTP increases BDNF mRNA (Castren et al., 1993) as well as trkB mRNA (Dragunow et al., 1997) in the DG. In addition, it has been shown that hippocampal LTP and spatial learning are impaired in mice lacking BDNF (Korte et al., 1995; Linnarsson et al., 1997) as well as in mice lacking trkB (Minichiello et al., 1999).

Collectively, these data indicated that BDNF via trkB plays an essential role in neuronal plasticity within the hippocampus. Along this line it has been shown in 2008 that BDNF is necessary and sufficient to induce long-lasting structural changes at dendritic spines that are associated with synaptic plasticity (Tanaka et al., 2008). Thus, BDNF seems to play an important role in synaptic plasticity, probably through induction of morphological changes.

Based on the age-related decline in the expression of BDNF and trkB in the hippocampus, one would expect that BDNF-induced LTP may be weaker in aged than in adult animals. Concerning this, it has been shown that in aged rats, BDNF-LTP is significantly impaired within the hippocampus and that the activation of trkB is reduced in hippocampal tissue derived from aged rats (Gooney et al., 2004).

Given the importance of BDNF for spatial learning and synaptic plasticity, it is not surprisingly that adult heterozygous BDNFdeficient mice have problems in solving spatial tasks such as the Morris water maze (Linnarsson et al., 1997). Given the age-dependent 
reduction in the BDNF-system, aged heterozygous BDNF-deficient mice should have great problems to solve spatial memory tasks. Indeed, by comparing adult and aged heterozygous BDNF knockout mice with age-matched $\mathrm{BDNF}^{+/+}$mice, Linnarsson et al. (1997) could show that aged wild-type mice performed significantly worse than young wild-type mice and the effect was even more pronounced in the aged BDNF mutant mice, which did not learn at all.

\section{BDNF AND HIPPOCAMPAL VOLUME}

The above-mentioned involvements of BDNF in structural changes and in neuronal plasticity in the hippocampus could indeed hint that BDNF via trkB has an impact upon hippocampal volume. Since BDNF seems also to be involved in several age-related alterations within the hippocampus, it is possible that age-related changes in hippocampal volume will be influenced by the action of this neurotrophin.

In humans, several polymorphisms of the BDNF gene have been discovered, as e.g. the functional Val66Met polymorphism in the coding region of the BDNF gene. Currently, there is a controversy whether the Val66Met polymorphism is associated with hippocampal volume change and depression or schizophrenia (Szeszko et al., 2005; Jessen et al., 2009; Koolschijn et al., 2009; Toro et al., 2009; Benjamin et al., 2010). However, there are reports indicating that the BDNF Val66Met allele is associated with reduced hippocampal volume in healthy subjects (Bueller et al., 2006; Erickson et al., 2010). Thus, reduced levels or lack of functional BDNF may contribute to volume reductions in the hippocampus. Data obtained from heterozygous BDNF knockout mice indicate a hippocampal volume reduction (Lee et al., 2002; Magarinos et al., 2010), likewise heterozygous trkB mice also display a reduction in hippocampal volume (von Bohlen und Halbach et al., 2003). Based on these results it can be speculated that there is a link between hippocampal volume and BDNF, but is BDNF associated with age-related declines in hippocampal volume? This question is answered by a study from Erickson and coworkers. They found that increasing age was associated with smaller hippocampal volumes, reduced levels of serum BDNF, and poorer memory performance in humans. According to their results, reduction in hippocampal volume mediates the age-related decline in spatial memory and BDNF mediates the age-related decline in hippocampal volume (Erickson et al., 2010). Thus, there is evidence to suggest that BDNF is a critical player, involved in the maintenance of the hippocampal volume in the adult hippocampus. Such a role for BDNF may not only be postulated for hippocampal volume changes seen during aging, but may also be proposed for hippocampal volume changes that are associated with psychopathological conditions.

\section{BDNF AND ALZHEIMER DISEASE}

Alzheimer's disease and Parkinson's disease are the most common age-related degenerative disorders of the human brain. A hallmark of Alzheimer's disease is the progressive reduction of the hippocampal volume and stereological investigations have confirmed the substantial hippocampal cell loss seen in AD (West et al., 2000; Price et al., 2001).

Alzheimer's disease is further characterized by a strong reduction of the cholinergic innervation of the brain, including the hippocampus, and the occurrence of beta-amyloid plaques and Tau/neurofibrillary tangles. The plaques are mainly composed of amyloid beta-peptide (Aß), a 40-42 amino acid fragment of the beta-amyloid precursor (APP), whereas the tangles are mainly composed of helical filament of hyperphosphorylated tau.

Concerning a possible role of BDNF in Alzheimer's disease, there is a controversy, whether polymorphisms in the BDNF gene are associated with Alzheimer's disease. Thus, there are reports indicating that there exists an association between the BDNF gene polymorphisms and Alzheimer's disease (Kunugi et al., 2001; Ventriglia et al., 2002; Feher et al., 2009), whereas other groups did not find an association in various populations (Combarros et al., 2004; Nishimura et al., 2004; Li et al., 2005; He et al., 2007).

Concerning the hippocampus, it has been shown that BDNF mRNA expression (Phillips et al., 1991; Murray et al., 1994) as well as BDNF protein (Connor et al., 1997) are decreased in individuals that had suffered from Alzheimer's disease. Post-mortem brains from Alzheimer's disease patients display an absence of BDNF in reactive glia cells of microglia cells (Soontornniyomkij et al., 1999) and an absence of BDNF in neurons containing neurofibrillary tangles, whereas most neurons, intensely immunoreactive for BDNF, did not exhibit massive neurofibrillary degeneration (Murer et al., 1999). Thus, the age-related decline in BDNF could contribute to age-related changes seen in conditions of normal aging, whereas further disturbances in the BDNF-system may be related to pathological changes in the brain. Along this line, there is not only evidence to suggest that disturbances in the hippocampal BDNF-system contribute to neurodegenerative diseases, as e.g. Alzheimer's disease, but also to psychopathological conditions, as e.g. depression.

\section{BDNF AND DEPRESSION}

Depression is a disorder of the representation and regulation of mood and emotion. Depression has profound impact upon several brain structures, as e.g. the hippocampal formation (Campbell and Macqueen, 2004). Concerning the hippocampus, several groups have reported that the hippocampal volume is smaller in depressed patients as compared to controls (Mervaala et al., 2000; Frodl et al., 2002; Lange and Irle, 2004). An interesting aspect of antidepressant treatment is that it is capable of blocking or reversing hippocampal atrophy that is observed in patients with depression (Schmidt and Duman, 2007). The dendritic spines represent a possible anatomical substrate for the depression-induced changes in the hippocampus. A variety of studies indicate that depression is accompanied by reductions in dendritic arborization (Lucassen et al., 2006) and in the spine densities within the hippocampus and that treatment with antidepressants can ameliorate or reverse these reductions in spine densities (Norrholm and Ouimet, 2001; Pittenger and Duman, 2008; Hajszan et al., 2009). Moreover, in animal models of depression ("learned helplessness"), an exacerbated age-related loss of serotonergic fiber density in area CA1 has been observed (Aznar et al., 2010).

Antidepressant treatment increases hippocampal BDNF mRNA expression (Garza et al., 2004) as well as BDNF-immunoreactivity (Chen et al., 2001). In addition, BDNF produces antidepressant effects in behavioral models of depression (Shirayama et al., 2002). Moreover, activation of trkB receptors is induced by antidepressant drugs and this receptor activation is required for antidepressantinduced behavioral effects (Saarelainen et al., 2003). Since BDNF is capable of increasing dendritic spine densities, it is likely that BDNF has a beneficial effect upon the disturbed neuronal plasticity seen in 
depression. Antidepressant treatments may, through enhanced BDNF signaling, improve the ability of critical brain circuits to respond optimally to environmental demands, a process that may be critical in the recovery from depression (Castren and Rantamaki, 2008) and drugs that selectively stimulate the production of neurotrophins could represent a new generation of antidepressants (Altar, 1999).

\section{SUMMARY}

BDNF is required in the postnatal brain, playing an important role in the maintenance of the brain architecture. Reductions in BDNF, seen either during normal aging, or in pathological conditions, are related to declines in neuronal plasticity and changes in the morphology of hippocampal neurons. These alterations could result in hippocampal dysfunctions and could contribute to hippocampal atrophy, seen during normal aging or in Alzheimer's disease. Concerning depression, a variety of studies suggests a critical role of neurotrophins, such as BDNF, in regulating neuronal morphology and neuronal plasticity. Alterations in neuronal plasticity accompanied by changes in the architecture of the hippocampus are also observed during normal aging (Table 1). Since there is an age-related decline in the expression of BDNF and since alterations in BDNF levels have effects upon the morphology of hippocampal neurons as well as on hippocampal neuronal plasticity, BDNF may represent a candidate that plays a critical role in age-related changes, at least in the hippocampus.

\section{ACKNOWLEDGMENT}

This work was supported by the DFG (BO 1971/5-1).

\section{REFERENCES}

Ader, J. P., Room, P., Postema, F., and Korf, J. (1980). Bilaterally diverging axon collaterals and contralateral projections from rat locus coeruleus neurons, demonstrated by fluorescent retrograde double labeling and norepinephrine metabolism. J. Neural Transm. 49, 207-208.

Alonso, M., Medina, J. H., and PozzoMiller, L. (2004). ERK1/2 activation is necessary for BDNF to increase dendritic spine density in hippocampal CAl pyramidal neurons. Learn Mem 11, 172-178.

Altar, C. A. (1999). Neurotrophins and depression. Trends Pharmacol. Sci. 20,59-61.

Auffret, A., Gautheron, V., Mattson, M. P., Mariani, J., and Rovira, C. (2010). Progressive age-related impairment of the late long-term potentiation in Alzheimer's disease presenilin-1 mutant knock-in mice. J. Alzheimers Dis. 19, 1021-1033.

Aznar, S., Klein, A. B., Santini, M. A., Knudsen, G. M., Henn, F., Gass, P., and Vollmayr, B. (2010). Aging and depression vulnerability interaction results in decreased serotonin innervation associated with reduced BDNF levels in hippocampus of rats bred for learned helplessness. Synapse 64, 561-565.
Ball, M. J. (1977). Neuronal loss, neurofibrillary tangles and granulovacuolar degeneration in the hippocampus with ageing and dementia. A quantitative study. Acta Neuropathol. 37, 111-118.

Barbacid, M. (1994). The Trk family of neurotrophin receptors. J. Neurobiol. 25, 1386-1403.

Barili, P., De Carolis, G., Zaccheo, D., and Amenta, F. (1998). Sensitivity to ageing of the limbic dopaminergic system: a review. Mech. Ageing Dev. 106, 57-92.

Barnes, C. A. (1987). Neurological and behavioral investigations of memory failure in aging animals. Int. J. Neurol. 21-22, 130-136.

Benjamin, S., McQuoid, D. R., Potter, G. G., Payne, M. E., Macfall, J. R., Steffens, D. C., and Taylor, W. D. (2010). The brain-derived neurotrophic factor Val66Met polymorphism, hippocampal volume, and cognitive function in geriatric depression. Am. J. Geriatr. Psychiatry 18, 323-331.

Bondareff, W. (1979). Synaptic atrophy in the senescent hippocampus. Mech. Ageing Dev. 9, 163-171.

Bruel-Jungerman, E., Davis, S., Rampon, C., and Laroche, S. (2006). Long-term potentiation enhances neurogenesis in the adult dentate gyrus. J. Neurosci. 26, 5888-5893.

Table 1 | Changes in the hippocampus or in hippocampus-dependent functions.

\begin{tabular}{|c|c|c|c|c|}
\hline & Aging & $\begin{array}{l}\text { Alzheimer } \\
\text { disease }\end{array}$ & Depression & $\begin{array}{l}\text { trkB- or } \\
\text { BDNF- } \\
\text { deficient } \\
\text { mice }\end{array}$ \\
\hline $\begin{array}{l}\text { Hippocampal } \\
\text { volume }\end{array}$ & Reduced & Reduced & Reduced & Reduced \\
\hline $\begin{array}{l}\text { Loss of } \\
\text { hippocampal } \\
\text { neurons }\end{array}$ & No & Yes & No & Minor \\
\hline $\begin{array}{l}\text { Hippocampal } \\
\text { spine } \\
\text { densities }\end{array}$ & Reduced & & Reduced & Reduced \\
\hline Neurogenesis & Reduced & Increased ${ }^{1}$ & Reduced & Reduced ${ }^{2}$ \\
\hline LTP & Reduced & Reduced $^{3}$ & Reduced $^{4}$ & Reduced \\
\hline Spatial learning & Reduced & Reduced 5 & Reduced $^{6}$ & Reduced \\
\hline
\end{tabular}

Several of these alterations are also seen in trkB- or BDNF-deficient mouse models.

'Jin et al. (2004).

${ }^{2}$ As determined by a trkB-deficient mouse line (Li et al., 2008).

${ }^{3}$ Data from mouse models of $A D$ (Nalbantoglu et al., 1997; Smith et al., 2009, Auffret et al., 2010; Gengler et al., 2010).

${ }^{4}$ Data from "learned helplessness," an animal model of depression (Ryan et al., 2009).

${ }^{5}$ Data from mouse models of AD (Moran et al., 1995; Nalbantoglu et al., 1997; Gordon et al., 2001).

6Data from "learned helplessness" (Song et al., 2006).

Bueller, J. A., Aftab, M., Sen, S., GomezHassan, D., Burmeister, M., and Zubieta, J. K. (2006). BDNF Val66Met allele is associated with reduced hippocampal volume in healthy subjects. Biol. Psychiatry 59, 812-815.

Burke, M. A., Mobley, W, C., Cho, J., Wiegand, S. J., Lindsay, R. M., Mufson, E. J., and Kordower, J. H. (1994). Loss of developing cholinergic basal forebrain neurons following excitotoxic lesions of the hippocampus: rescue by neurotrophins. Exp. Neurol. 130, 178-195.

Calhoun, M. E., Kurth, D., Phinney, A. L. Long, J. M., Hengemihle, J., Mouton, P. R., Ingram, D. K., and Jucker, M. (1998). Hippocampal neuron and synaptophysin-positive bouton number in aging C57BL/6 mice. Neurobiol. Aging 19, 599-606.

Campbell, S., and Macqueen, G. (2004). The role of the hippocampus in the pathophysiology of major depression. J. Psychiatry Neurosci. 29 417-426.

Castren, E., Pitkanen, M., Sirvio, J., Parsadanian, A., Lindholm, D., Thoenen, H., and Riekkinen, P. J. (1993). The induction of LTP increases BDNF and NGF mRNA but decreases NT-3 mRNA in the dentate gyrus. NeuroReport 4, 895-898.
Castren, E., and Rantamaki, T. (2008). Neurotrophins in depression and antidepressant effects. Novartis Found Symp. 289, 43-52.

Chan-Palay, V., and Asan, E. (1989). Quantitation of catecholamine neurons in the locus coeruleus in human brains of normal young and older adults and in depression. J. Comp. Neurol. 287, 357-372.

Chen, B., Dowlatshahi, D., MacQueen, G. M., Wang, J. F., and Young, L. T. (2001). Increased hippocampal BDNF immunoreactivity in subjects treated with antidepressant medication. Biol. Psychiatry 50, 260-265.

Chourbaji, S., Hellweg, R., Brandis, D., Zorner, B., Zacher, C., Lang, U. E., Henn, F. A., Hortnagl, H., and Gass, P. (2004). Mice with reduced brain-derived neurotrophic factor expression show decreased choline acetyltransferase activity, but regular brain monoamine levels and unaltered emotional behavior. Brain Res. Mol. Brain Res. 121, 28-36.

Combarros, O., Infante, J., Llorca, J., and Berciano, J. (2004). Polymorphism at codon 66 of the brain-derived neurotrophic factor gene is not associated with sporadic Alzheimer's disease. Dement. Geriatr. Cogn. Disord. 18, 55-58. 
Connor, B., Young, D., Yan, Q., Faull, R. L., Synek, B., and Dragunow, M. (1997). Brain-derived neurotrophic factor is reduced in Alzheimer's disease. Brain Res Mol. Brain Res. 49, 71-81.

Convit, A., de Leon, M. J., Hoptman, M. J., Tarshish, C., De, S. S., and Rusinek, H. (1995). Age-related changes in brain: I. Magnetic resonance imaging measures of temporal lobe volumes in normal subjects. Psychiatr. Q. 66, 343-355.

Croll, S. D., Ip, N. Y., Lindsay, R. M., and Wiegand, S. J. (1998). Expression of $\mathrm{BDNF}$ and trkB as a function of age and cognitive performance. Brain Res. 812, 200-208.

Curcio, C. A., and Hinds, J. W. (1983). Stability of synaptic density and spine volume in dentate gyrus of aged rats. Neurobiol. Aging 4, 77-87.

Danzer, S. C., Crooks, K. R., Lo, D. C., and McNamara, J. O. (2002). Increased expression of brain-derived neurotrophic factor induces formation of basal dendrites and axonal branching in dentate granule cells in hippocampal explant cultures. J. Neurosci. 22, 9754-9763.

Dluzen, D. E., Story, G. M., Xu, K., Kucera, J., and Walro, J. M. (1999). Alterations in nigrostriatal dopaminergic function within BDNF mutant mice. Exp. Neurol. 160, 500-507.

Dragunow, M, Hughes, P., Mason-Parker, S. E., Lawlor, P., and Abraham, W. C. (1997). TrkB expression in dentate granule cells is associated with a late phase of long-term potentiation. Brain Res. Mol. Brain Res. 46, 274-280.

Drapeau, E., Mayo, W., Aurousseau, C., Le, M. M., Piazza, P. V., and Abrous, D. N. (2003). Spatial memory performances of aged rats in the water maze predict levels of hippocampal neurogenesis. Proc. Natl. Acad. Sci. U.S.A. 100, 14385-14390.

Driscoll, I., Hamilton, D. A., Petropoulos, H., Yeo, R. A., Brooks, W. M., Baumgartner, R. N., and Sutherland, R. J. (2003). The aging hippocampus: cognitive, biochemical and structural findings. Cereb. Cortex 13 , 1344-1351.

Engert, F., and Bonhoeffer, T. (1999). Dendritic spine changes associated with hippocampal long-term synaptic plasticity. Nature 399, 66-70.

Erickson, K. I., Prakash, R. S., Voss, M. W., Chaddock, L., Heo, S., McLaren, M., Pence, B. D., Martin, S. A., Vieira, V. J., Woods, J. A., McAuley, E., and Kramer, A. F. (2010). Brain-derived neurotrophic factor is associated with age-related decline in hippocampal volume. J. Neurosci. 30, 5368-5375.

Everitt, B. J., and Robbins, T. W. (1997). Central cholinergic systems and cognition. Annu. Rev. Psychol. 48, 649-684.

Feher, A., Juhasz, A., Rimanoczy, A., Kalman, J., and Janka, Z. (2009). Association between BDNF Val66Met polymorphism and Alzheimer disease, dementia with Lewy bodies, and Pick disease. Alzheimer Dis. Assoc. Disord. 23, 224-228.

Fiala, J. C., Spacek, J., and Harris, K. M. (2002). Dendritic spine pathology: cause or consequence of neurological disorders? Brain Res. Brain Res. Rev. 39, 29-54.

Frodl, T., Meisenzahl, E. M., Zetzsche, T., Born, C., Groll, C., Jager, M. Leinsinger, G., Bottlender, R., Hahn, K., and Moller, H.J. (2002). Hippocampal changes in patients with a first episode of major depression. Am. J. Psychiatry 159, 1112-1118.

Galter, D., and Unsicker, K. (2000). Sequential activation of the 5-HT1(A) serotonin receptor and TrkB induces the serotonergic neuronal phenotype. Mol. Cell Neurosci. 15, 446-455.

Garza,A.A., Ha, T. G., Garcia, C., Chen, M. J., and Russo-Neustadt, A. A. (2004), Exercise, antidepressant treatment, and BDNF mRNA expression in the aging brain. Pharmacol. Biochem. Behav. 77, 209-220.

Gasbarri, A., Verney, C., Innocenzi, R. Campana, E., and Pacitti, C. (1994). Mesolimbic dopaminergic neurons innervating the hippocampal formation in the rat: a combined retrograde tracing and immunohistochemical study. Brain Res. 668, 71-79.

Gazzaley, A.H., Thakker, M.M., Hof, P. R., and Morrison, J. H. (1997). Preserved number of entorhinal cortex layer II neurons in aged macaque monkeys. Neurobiol. Aging 18, 549-553.

Geinisman, Y. (2000). Structural synaptic modifications associated with hippocampal LTP and behavioral learning. Cereb. Cortex 10, 952-962.

Geinisman, Y., Bondareff, W., and Dodge, J. T. (1978). Dendritic atrophy in the dentate gyrus of the senescent rat. Am. J. Anat. 152, 321-329.

Gengler, S., Hamilton, A., and Holscher, C. (2010). Synaptic plasticity in the hippocampus of a APP/PS1 mouse model of Alzheimer's disease is impaired in old but not young mice. PLoS One 5, e9764. doi:10.1371/journal.pone.0009764.

Gilad, G. M., Rabey, J. M., Tizabi, Y., and Gilad, V. H. (1987). Age-dependent loss and compensatory changes of septohippocampal cholinergic neurons in two rat strains differing in longevity and response to stress. Brain Res. 436, 311-322.

Gooney, M., Messaoudi, E., Maher, F. O. Bramham, C. R., and Lynch, M. A.
(2004). BDNF-induced LTP in dentate gyrus is impaired with age: analysis of changes in cell signaling events. Neurobiol. Aging 25, 1323-1331.

Gordon, M. N., King, D. L., Diamond, D. M., Jantzen, P. T., Boyett, K. V., Hope, C. E., Hatcher, J. M., DiCarlo, G., Gottschall, W. P., Morgan, D., and Arendash, G. W. (2001). Correlation between cognitive deficits and Abeta deposits in transgenic APP + PS1 mice. Neurobiol. Aging 22, 377-385.

Gould,E., Reeves, A. J., Fallah, M., Tanapat, P., Gross, C. G., and Fuchs, E. (1999). Hippocampal neurogenesis in adult Old World primates. Proc. Natl. Acad. Sci. U.S.A. 96, 5263-5267.

Greene, E., and Naranjo, J. N. (1987). Degeneration of hippocampal fibers and spatial memory deficit in the aged rat. Neurobiol. Aging 8, 35-43.

Grosse, G., Djalali, S., Deng, D. R., Holtje, M., Hinz, B., Schwartzkopff, K., Cygon, M., Rothe, T., Stroh, T. Hellweg, R., Hnert-Hilger, G., and Hortnag, H. (2005). Area-specific effects of brain-derived neurotrophic factor (BDNF) genetic ablation on various neuronal subtypes of the mouse brain. Brain Res. Dev. Brain Res. 156, 111-126.

Gundersen, H. J., Jensen, E. B., Kieu, K., and Nielsen, J. (1999). The efficiency of systematic sampling in stereology reconsidered. J. Microsc. 193, 199-211.

Hagg, T. (1998). Neurotrophins prevent death and differentially affect tyrosine hydroxylase of adult rat nigrostriatal neurons in vivo. Exp. Neurol. 149 183-192.

Hajszan, T., Dow, A., Warner-Schmidt, J. L., Szigeti-Buck, K., Sallam, N. L., Parducz, A., Leranth, C., and Duman, R. S. (2009). Remodeling of hippocampal spine synapses in the rat learned helplessness model of depression. Biol. Psychiatry 65, 392-400.

Hayashi, M., Mistunaga, F., Ohira, K., and Shimizu, K. (2001). Changes in BDNF-immunoreactive structures in the hippocampal formation of the aged macaque monkey. Brain Res. 918 191-196.

He, X. M., Zhang, Z. X., Zhang, J. W. Zhou, Y.T., Tang, M.N., Wu, C. B., and Hong, Z. (2007). Lack of association between the BDNF gene Val66Met polymorphism and Alzheimer disease in a Chinese Han population. Neuropsychobiology 55, 151-155.

Head, D., and Isom, M. (2010). Age effects on wayfinding and route learning skills. Behav. Brain Res. 209, 49-58.

Hyman, C., Hofer, M., Barde, Y. A., Juhasz, M., Yancopoulos, G. D., Squinto, S. P., and Lindsay, R. M. (1991). BDNF is a neurotrophic factor for dopaminergic neurons of the substantia nigra. Nature 350, 230-232.

Iaria, G., Palermo, L., Committeri, G., and Barton, J. J. (2009). Age differences in the formation and use of cognitive maps. Behav. Brain Res. 196, 187-191.

Ishida Y, Shirokawa, T., Miyaishi, O. Komatsu, Y., and Isobe, K. (2000). Age-dependent changes in projections from locus coeruleus to hippocampus dentate gyrus and frontal cortex. Eur. J. Neurosci. 12, 1263-1270.

Jessen, F., Schuhmacher, A., von, W. O., Guttenthaler, V., Hofels, S., Suliman, H., Scheef, L., Block, W., Urbach, H., Maier, W., and Zobel, A. (2009). No association of the Val66Met polymorphism of the brain-derived neurotrophic factor with hippocampal volume in major depression. Psychiatr. Genet. 19, 99-101.

Jin, K., Peel, A. L., Mao, X. O., Xie, L., Cottrell, B. A., Henshall, D. C., and Greenberg, D. A. (2004). Increased hippocampal neurogenesis in Alzheimer's disease. Proc. Natl. Acad. Sci. U.S.A. 101, 343-347.

Kafitz, K.W., Rose, C. R., Thoenen, H., and Konnerth, A. (1999). Neurotrophinevoked rapid excitation through TrkB receptors. Nature 401, 918-921.

Kang, H., and Schuman, E. M. (1995). Long-lasting neurotrophin-induced enhancement of synaptic transmission in the adult hippocampus. Science 267 1658-1662.

Karege, F., Schwald, M., and Cisse, M. (2002). Postnatal developmental profile of brain-derived neurotrophic factor in rat brain and platelets. Neurosci. Lett. 328, 261-264.

Katoh-Semba, R., Semba, R., Takeuchi, I. K., and Kato, K. (1998). Age-related changes in levels of brain-derived neurotrophic factor in selected brain regions of rats, normal mice and senescence-accelerated mice: a comparison to those of nerve growth factor and neurotrophin-3.Neurosci. Res. 31, 227-234.

Kawaguchi, S., Kishikawa, M., Sakae, M., and Nakane, Y. (1995). Age-related changes in basal dendrite and dendritic spine of hippocampal pyramidal neurons (CA1) among SAMP1TA/ Ngs - quantitative analysis by the rapid Golgi method. Mech. Ageing Dev. 83, 11-20.

Kempermann, G., Kuhn, H. G., and Gage, F. H. (1997). More hippocampal neurons in adult mice living in an enriched environment. Nature 386, 493-495.

Konur, S., Rabinowitz, D., Fenstermaker, V. L., and Yuste, R. (2003). Systematic regulation of spine sizes and densities in pyramidal neurons. J. Neurobiol. 56, 95-112. 
Koolschijn, P. C., van Haren, N. E., Bakker, S. C., Hoogendoorn, M. L., Pol, H. E., and Kahn, R. S. (2009). Effects of brain-derived neurotrophic factor Val66Met polymorphism on hippocampal volume change in schizophrenia. Hippocampus in press. doi: 10.1002/ hipo.20699. [Epub ahead of print]

Korte, M., Carroll, P., Wolf, E., Brem, G., Thoenen, H., and Bonhoeffer, T. (1995). Hippocampal long-term potentiation is impaired in mice lacking brain-derived neurotrophic factor. Proc. Natl. Acad. Sci. U.S.A. 92, 8856-8860.

Kuhn, H. G., Dickinson-Anson, H., and Gage, F. H. (1996). Neurogenesis in the dentate gyrus of the adult rat: age-related decrease of neuronal progenitor proliferation. J. Neurosci. 16, 2027-2033.

Kunugi, H., Ueki, A., Otsuka, M., Isse, K., Hirasawa, H., Kato, N., Nabika, T., Kobayashi, S., and Nanko, S. (2001). A novel polymorphism of the brain-derived neurotrophic factor (BDNF) gene associated with late-onset Alzheimer's disease. Mol. Psychiatry 6, 83-86.

Landfield, P. W., Thibault, O., Mazzanti, M. L., Porter, N, M., and Kerr, D, S. (1992). Mechanisms of neuronal death in brain aging and Alzheimer's disease: role of endocrine-mediated calcium dyshomeostasis. J. Neurobiol. 23, 1247-1260.

Lange, C., and Irle, E. (2004). Enlarged amygdala volume and reduced hippocampal volume in young women with major depression. Psychol. Med. 34, 1059-1064.

Lee, J., Duan, W., and Mattson, M. P. (2002). Evidence that brain-derived neurotrophic factor is required for basal neurogenesis and mediates, in part, the enhancement of neurogenesis by dietary restriction in the hippocampus of adult mice. J. Neurochem. 82, 1367-1375.

Lee, J. M., Ross, E. R., Gower, A., Paris, J. M., Martensson, R., and Lorens, S. A. (1994). Spatial learning deficits in the aged rat: neuroanatomical and neurochemical correlates. Brain Res. Bull. 33, 489-500.

Leuner, B., Falduto, J., and Shors, T. J. (2003). Associative memory formation increases the observation of dendritic spines in the hippocampus. J. Neurosci. 23, 659-665.

Leuner, B., and Shors, T. J. (2004). New spines, new memories. Mol. Neurobiol. 29, 117-130.

Li, Y., Luikart, B. W., Birnbaum, S., Chen, J., Kwon, C. H., Kernie, S. G., BasselDuby, R., and Parada, L. F. (2008). TrkB regulates hippocampal neurogenesis and governs sensitivity to antidepressive treatment. Neuron 59, 399-412.
Li, Y., Rowland, C., Tacey, K., Catanese, J., Sninsky, J., Hardy, J., Powell, J., Lovestone, S., Morris, J. C., Thal, L. Goate, A., Owen, M., Williams, J., and Grupe,A. (2005). The BDNFVal66Met polymorphism is not associated with late onset Alzheimer's disease in three case-control samples. Mol. Psychiatry 10, 809-810.

Linnarsson, S., Bjorklund, A., and Ernfors, P. (1997). Learning deficit in BDNF mutant mice. Eur. J. Neurosci. 9, 2581-2587.

Lohr, J. B., and Jeste, D. V. (1988). Locus ceruleus morphometry in aging and schizophrenia. Acta. Psychiatr. Scand. 77, 689-697.

Lolova, I. (1989). Dendritic changes in the hippocampus of aged rats. Acta. Morphol. Hung. 37, 3-10.

Lolova, I., and Davidoff, M. (1992). Age-related changes in serotoninimmunoreactive neurons in the rat nucleus raphe dorsalis and nucleus centralis superior: a light microscope study. Mech. Ageing Dev. 62, 279-289.

Lolova, I., Lolov, V., and Petkov, V. D. (1989). Quantification of the synapses in the hippocampus of aged rats. $Z$. Mikrosk. Anat. Forsch. 103, 447-458.

Lommatzsch, M.,Zingler, D., Schuhbaeck, K., Schloetcke, K., Zingler, C., SchuffWerner, P., and Virchow, J. C. (2005). The impact of age, weight and gender on BDNF levels in human platelets and plasma. Neurobiol. Aging 26, 115-123.

Lucassen, P. J., Heine, V. M., Muller, M. B., van der Beek, E. M., Wiegant, V. M., de Kloet, E. R., Joels, M., Fuchs, E., Swaab, D. F., and Czeh, B. (2006). Stress, depression and hippocampal apoptosis. CNS Neurol. Disord. Drug Targets 5, 531-546.

Luebke, J. I., and Rosene, D. L. (2003). Aging alters dendritic morphology, input resistance, and inhibitory signaling in dentate granule cells of the rhesus monkey. J. Comp. Neurol. 460, 573-584.

Luellen, B. A., Bianco, L. E., Schneider, L. M., and Andrews, A. M. (2007). Reduced brain-derived neurotrophic factor is associated with a loss of serotonergic innervation in the hippocampus of aging mice. Genes Brain Behav. 6, 482-490.

Magarinos, A. M., Li, C. J., Toth, J. G., Bath, K. G., Jing, D., Lee, F. S., and McEwen, B. S. (2010). Effect of brain-derived neurotrophic factor haploinsufficiency on stress-induced remodeling of hippocampal neurons. Hippocampus doi: 10.1002/hipo.20699. [Epub ahead of print].

Malykhin, N.V., Bouchard, T.P., Camicioli, R., and Coupland, N. J. (2008). Aging hippocampus and amygdala. Neuroreport 19, 543-547.
Mamounas, L. A., Altar, C. A., Blue, M. E., Kaplan, D. R., Tessarollo, L., and Lyons, W. E. (2000). BDNF promotes the regenerative sprouting, but not survival, of injured serotonergic axons in the adult rat brain. J. Neurosci. 20 , 771-782.

Manaye, K. F., McIntire, D. D., Mann, D. M., and German, D. C. (1995). Locus coeruleus cell loss in the aging human brain: a non-random process. J. Comp. Neurol. 358, 79-87.

Mani, R. B., Lohr, J. B., and Jeste, D. V. (1986). Hippocampal pyramidal cells and aging in the human: quantitative study of neuronal loss in sectors CA1 to CA4. Exp. Neurol. 94, 29-40.

Markham, J. A., McKian, K. P., Stroup, T. S., and Juraska, J. M. (2005). Sexually dimorphic aging of dendritic morphology in CA1 of hippocampus. Hippocampus 15, 97-103.

Matsunaga, W., Isobe, K., and Shirokawa T. (2006). Involvement of neurotrophic factors in aging of noradrenergic innervations in hippocampus and frontal cortex. Neurosci. Res. 54 313-318.

Matsunaga, W., Shirokawa, T., and Isobe, K. (2004). BDNF is necessary for maintenance of noradrenergic innervations in the aged rat brain. Neurobiol. Aging 25, 341-348.

Mattson, M. P., Maudsley, S., and Martin, B. (2004). BDNF and 5-HT: a dynamic duo in age-related neuronal plasticity and neurodegenerative disorders. Trends Neurosci. 27, 589-594.

Megias, M., Emri, Z., Freund, T. F., and Gulyas, A. I. (2001). Total number and distribution of inhibitory and excitatory synapses on hippocampal CA1 pyramidal cells. Neuroscience 102 527-540.

Merrill, D. A., Chiba,A.A., and Tuszynski, M. H. (2001). Conservation of neuronal number and size in the entorhinal cortex of behaviorally characterized aged rats. J. Comp. Neurol. 438, 445-456.

Mervaala, E., Fohr, J., Kononen, M., Valkonen-Korhonen, M., Vainio, P. Partanen, K., Partanen, J., Tiihonen, J., Viinamaki, H., Karjalainen, A. K. and Lehtonen, J. (2000). Quantitative MRI of the hippocampus and amygdala in severe depression. Psychol. Med. 30, 117-125.

Miguez,J.M.,Aldegunde, M., Paz-Valinas, L., Recio, J., and Sanchez-Barcelo, E. (1999). Selective changes in the contents of noradrenaline, dopamine and serotonin in rat brain areas during aging. J. Neural. Transm. 106 1089-1098.

Ming, G. L., and Song, H. (2005). Adult neurogenesis in the mammalian central nervous system. Annu. Rev. Neurosci. 28, 223-250

Minichiello, L., Korte, M., Wolfer, D., Kuhn, R., Unsicker, K, Cestari, V., Rossi-Arnaud, C., Lipp, H. P., Bonhoeffer, T., and Klein, R. (1999). Essential role for TrkB receptors in hippocampus-mediated learning. Neuron 24, 401-414.

Moffat. S. D. (2009). Aging and spatial navigation: what do we know and where do we go? Neuropsychol. Rev. 19, 478-489.

Moran, P. M., Higgins, L. S., Cordell, B., and Moser, P. C. (1995). Age-related learning deficits in transgenic mice expressing the 751-amino acid isoform of human beta-amyloid precursor protein. Proc. Natl. Acad. Sci. U.S.A. 92, 5341-5345.

Moser, M. B., Trommald, M., and Andersen, P. (1994). An increase in dendritic spine density on hippocampal CA1 pyramidal cells following spatial learning in adult rats suggests the formation of new synapses. Proc. Natl. Acad. Sci. U.S.A. 91, 12673-12675.

Mu, Q., Xie, J., Wen, Z., Weng, Y., and Shuyun, Z. (1999). A quantitative MR study of the hippocampal formation, the amygdala, and the temporal horn of the lateral ventricle in healthy subjects 40 to 90 years of age. Am. J. Neuroradiol. 20, 207-211.

Muller, D., Toni, N., and Buchs, P. A. (2000). Spine changes associated with long-term potentiation. Hippocampus 10, 596-604.

Murer, M. G., Boissiere, F., Yan, Q., Hunot, S., Villares, J., Faucheux, B., Agid, Y., Hirsch, E., and Raisman-Vozari, R. (1999). An immunohistochemical study of the distribution of brainderived neurotrophic factor in the adult human brain, with particular reference to Alzheimer's disease. Neuroscience 88, 1015-1032.

Murray, K. D., Gall, C. M., Jones, E. G., and Isackson, P. J. (1994). Differential regulation of brain-derived neurotrophic factor and type II calcium/calmodulindependent protein kinase messenger RNA expression in Alzheimer's disease. Neuroscience 60, 37-48.

Nalbantoglu, J., Tirado-Santiago, G., Lahsaini, A., Poirier, J., Goncalves, O., Verge, G., Momoli, F., Welner, S. A., Massicotte, G., Julien, J. P., and Shapiro, M. L. (1997). Impaired learning and LTP in mice expressing the carboxy terminus of the Alzheimer amyloid precursor protein. Nature 387, 500-505.

Naoi, M., and Maruyama, W. (1999). Cell death of dopamine neurons in aging and Parkinson's disease. Mech Ageing Dev 111, 175-188. 
Niewiadomska, G., BaksalerskaPazera, M., and Riedel, G. (2009). The septo-hippocampal system, learning and recovery of function. Prog. Neuropsychopharmacol. Biol. Psychiatry 33, 791-805.

Nilsson, M., Perfilieva, E., Johansson, U., Orwar, O., and Eriksson, P. S. (1999). Enriched environment increases neurogenesis in the adult rat dentate gyrus and improves spatial memory. J. Neurobiol. 39, 569-578.

Nimchinsky, E. A., Sabatini, B. L., and Svoboda, K. (2002). Structure and function of dendritic spines. Annu. Rev. Physiol. 64, 313-353.

Nishimura, A., Ueda, S., Takeuchi, Y., Sawada, T., and Kawata, M. (1995). Age-related decrease of serotonergic fibres and S-100 beta immunoreactivity in the rat dentate gyrus. NeuroReport 6, 1445-1448.

Nishimura, A. L., Oliveira, J. R., MitneNeto, M., Guindalini, C., Nitrini, R., Bahia, V. S., de Brito-Marques, P. R., Otto, P.A., and Zatz, M. (2004). Lack of association between the brain-derived neurotrophin factor (C-270T) polymorphism and late-onset Alzheimer's disease (LOAD) in Brazilian patients. J. Mol. Neurosci. 22, 257-260.

Norrholm, S. D., and Ouimet, C. C. (2001).Altered dendritic spine density in animal models of depression and in response to antidepressant treatment. Synapse 42, 151-163.

Nunzi, M. G., Milan, F., Guidolin, D., and Toffano, G. (1987). Dendritic spineloss in hippocampus of aged rats. Effect of brain phosphatidylserine administration. Neurobiol. Aging 8, 501-510.

Ohm, T. G., Busch, C., and Bohl, J. (1997). Unbiased estimation of neuronal numbers in the human nucleus coeruleus during aging. Neurobiol. Aging 18, 393-399.

Phillips, H. S., Hains, J. M., Armanini, M., Laramee, G. R., Johnson, S. A., and Winslow, J. W. (1991). BDNF mRNA is decreased in the hippocampus of individuals with Alzheimer's disease. Neuron 7, 695-702.

Pittenger, C., and Duman, R. S. (2008). Stress, depression, and neuroplasticity: a convergence of mechanisms. Neuropsychopharmacology 33, 88-109.

Porritt, M. J., Batchelor, P. E., and Howells, D. W. (2005). Inhibiting BDNF expression by antisense oligonucleotide infusion causes loss of nigral dopaminergic neurons. Exp. Neurol. 192, 226-234.

Price, J.L., Ko, A. I., Wade, M. J., Tsou, S. K., McKeel, D.W., and Morris, J.C. (2001). Neuron number in the entorhinal cortex and CA1 in preclinical Alzheimer disease. Arch. Neurol. 58, 1395-1402.
Rapp, P. R., and Gallagher, M. (1996) Preserved neuron number in the hippocampus of aged rats with spatial learning deficits. Proc. Natl. Acad. Sci. U.S.A. 93, 9926-9930.

Rapp, P. R., and Heindel, W. C. (1994) Memory systems in normal and pathological aging. Curr. Opin. Neurol. 7, 294-298.

Rasmussen, T., Schliemann, T., Sorensen, J. C., Zimmer, J., and West, M. J. (1996). Memory impaired aged rats: no loss of principal hippocampal and subicular neurons. Neurobiol Aging 17, 143-147.

Raz, N., Ghisletta, P., Rodrigue, K. M., Kennedy, K. M., and Lindenberger, U. (2010). Trajectories of brain aging in middle-aged and older adults: regional and individual differences. Neuroimage 51, 501-511.

Robinson, T. E., Vanderwolf, C. H., and Pappas, B. A. (1977). Are the dorsal noradrenergic bundle projections from the locus coeruleus important for neocortical or hippocampal activation? Brain Res. 138, 75-98.

Rosenzweig, E. S., and Barnes, C.A. (2003). Impact of aging on hippocampal function: plasticity, network dynamics, and cognition. Prog. Neurobiol. 69 , 143-179.

Ryan, B. K., Vollmayr, B., Klyubin, I., Gass, P., and Rowan, M. J. (2009). Persistent inhibition of hippocampal longterm potentiation in vivo by learned helplessness stress. Hippocampus 20, 758-767.

Saarelainen, T., Hendolin, P., Lucas, G., Koponen,E.,Sairanen,M.,MacDonald, E., Agerman, K., Haapasalo, A., Nawa, H., Aloyz, R., Ernfors, P., and Castren, E. (2003). Activation of the TrkB neurotrophin receptor is induced by antidepressant drugs and is required for antidepressant-induced behavioral effects. J. Neurosci. 23, 349-357.

Schmidt, H. D., and Duman, R. S. (2007). The role of neurotrophic factors in adult hippocampal neurogenesis, antidepressant treatments and animal models of depressive-like behavior. Behav. Pharmacol. 18, 391-418.

Shirayama, Y., Chen, A. C., Nakagawa, S., Russell, D. S., and Duman, R. S. (2002). Brain-derived neurotrophic factor produces antidepressant effects in behavioral models of depression. J. Neurosci. 22, 3251-3261.

Siddiqi, Z., Kemper, T. L., and Killiany, R. (1999). Age-related neuronal loss from the substantia nigra-pars compacta and ventral tegmental area of the rhesus monkey. J. Neuropathol. Exp. Neurol. 58, 959-971.

Silhol, M., Bonnichon, V., Rage, F., and Tapia-Arancibia, L. (2005). Agerelated changes in brain-derived neurotrophic factor and tyrosine kinase receptor isoforms in the hippocampus and hypothalamus in male rats. Neuroscience 132, 613-624.

Smith, J. P., Lal, V., Bowser, D., Cappai, R. Masters, C. L., and Ciccotosto, G. D. (2009). Stimulus pattern dependence of the Alzheimer's disease amyloidbeta 42 peptide's inhibition of long term potentiation in mouse hippocampal slices. Brain Res. 1269, 176-84.

Snyder, J. S., Hong, N. S., McDonald, R. J., and Wojtowicz, J. M. (2005). A role for adult neurogenesis in spatia long-term memory. Neuroscience 130 843-852.

Song, L., Che, W., Min-Wei, W. Murakami, Y., and Matsumoto, K. (2006). Impairment of the spatial learning and memory induced by learned helplessness and chronic mild stress. Pharmacol. Biochem. Behav. 83 , 186-193.

Soontornniyomkij, V., Wang, G., Pittman, C.A., Hamilton, R. L., Wiley, C.A., and Achim, C. L. (1999). Absence of brainderived neurotrophic factor and trkB receptor immunoreactivity in glia of Alzheimer's disease. Acta Neuropathol (Berl) 98, 345-348.

Sterio, D. C. (1984). The unbiased estimation of number and sizes of arbitrary particles using the disector. J. Microsc. 134(Pt 2), 127-136.

Sykova, E., Mazel, T., Hasenohrl, R. U. Harvey, A. R., Simonova. Z., Mulders, W. H., and Huston, J. P. (2002) Learning deficits in aged rats related to decrease in extracellular volume and loss of diffusion anisotropy in hippocampus. Hippocampus 12, 269-279.

Szeszko, P. R., Lipsky, R., Mentschel, C. Robinson, D., Gunduz-Bruce, H., Sevy, S., Ashtari, M., Napolitano, B. Bilder, R. M., Kane, J. M., Goldman, D., and Malhotra, A. K. (2005). Brainderived neurotrophic factor val66met polymorphism and volume of the hippocampal formation. Mol. Psychiatry 10, 631-636

Tanaka, J., Horiike, Y., Matsuzaki, M. Miyazaki, T., Ellis-Davies, G. C., and Kasai, H. (2008). Protein synthesis and neurotrophin-dependent structural plasticity of single dendritic spines. Science 319, 1683-1687.

Tatton, W. G., Greenwood, C. E., Verrier, M. C., Holland, D. P., Kwan, M. M., and Biddle, F. E. (1991). Different rates of age-related loss for four murine monoaminergic neuronal populations. Neurobiol. Aging 12, 543-556.

Teng, K. K., and Hempstead, B. L. (2004). Neurotrophins and their receptors: signaling trios in complex biological systems. Cell Mol. Life Sci. 61, 35-48.

Tolwani, R. J., Buckmaster, P. S., Varma, S., Cosgaya, J. M., Wu, Y., Suri, C., and Shooter, E. M. (2002). BDNF overexpression increases dendrite complexity in hippocampal dentate gyrus. Neuroscience 114, 795-805.

Toni, N., Buchs, P. A., Nikonenko, I., Bron, C. R., and Muller, D. (1999). LTP promotes formation of multiple spine synapses between a single axon terminal and a dendrite. Nature 402 , 421-425.

Toro, R., Chupin, M., Garnero, L., Leonard, G., Perron, M., Pike, B., Pitiot, A., Richer, L., Veillette, S., Pausova, Z., and Paus, T. (2009). Brain volumes and Val66Met polymorphism of the BDNF gene: local or global effects? Brain Struct. Funct. 213, 501-509.

Traver, S., Marien, M., Martin, E., Hirsch, E. C., and Michel, P.P. (2006). The phenotypic differentiation of locus ceruleus noradrenergic neurons mediated by brain-derived neurotrophic factor is enhanced by corticotropin releasing factor through the activation of a cAMP-dependent signaling pathway. Mol. Pharmacol. 70, 30-40.

Tyler, W. J., and Pozzo-Miller, L. (2003). Miniature synaptic transmission and BDNF modulate dendritic spine growth and form in rat CA1 neurones. J. Physiol. 553, 497-509.

Uemura, E. (1985). Age-related changes in the subiculum of Macaca mulatta: dendritic branching pattern. Exp. Neurol. 87, 412-427.

Ventriglia, M., Bocchio, C. L., Benussi, L., Binetti, G., Zanetti, O., Riva, M. A., and Gennarelli, M. (2002). Association between the BDNF $196 \mathrm{~A} / \mathrm{G}$ polymorphism and sporadic Alzheimer's disease. Mol. Psychiatry 7, 136-137.

von Bohlen und Halbach, O. (2009). Structure and function of dendritic spines within the hippocampus. Ann. Anat. 191, 518-531.

von Bohlen und Halbach, O., Krause, S., Medina, D., Sciarretta, C., Minichiello, L., and Unsicker, K. (2006a). Regionaland age-dependent reduction in trkB receptor expression in the hippocampus is associated with altered spine morphologies. Biol. Psychiatry 59, 793-800.

von Bohlen und Halbach, O., Zacher, C., Gass, P., and Unsicker, K. (2006b). Age-related alterations in hippocampal spines and deficiencies in spatial memory in mice. J. Neurosci. Res. 83, 525-531.

von Bohlen und Halbach, O., Minichiello, L., and Unsicker, K. (2003). Haploinsufficiency in trkB and/or trkC neurotrophin receptors causes structural alterations in the aged hippocampus and amygdala. Eur. J. Neurosci. 18, 2319-2325.

von Bohlen und Halbach, O., Minichiello, L., and Unsicker, K. (2005). 
Haploinsufficiency for trkB and trkC receptors induces cell loss and accumulation of alpha-synuclein in the substantia nigra. FASEB J. 19, 1740-1742.

von Bohlen und Halbach, O., Minichiello, L., and Unsicker, K. (2008). TrkB but not trkC receptors are necessary for postnatal maintenance of hippocampal spines. Neurobiol Aging 29, 1247-1255.

von Bohlen und Halbach, O., and Unsicker, K. (2002). Morphological alterations in the amygdala and hippocampus of mice during aging. Eur. J. Neurosci. 16, 2434-2440.

von Bohlen und Halbach, O., and Unsicker, K. (2003). Age-related decline in the tyrosine hydroxylase-immunoreactive innervation of the amygdala and dentate gyrus in mice. Cell Tissue Res. 311, 139-143.

Walker, L. C., Kitt, C. A., Struble, R. G., Wagster, M. V., Price, D. L., and Cork, L. C. (1988). The neural basis of memory decline in aged monkeys. Neurobiol. Aging 9, 657-666.
Ward, M. T., Oler, J. A., and Markus, E. J. (1999). Hippocampal dysfunction during aging I: deficits in memory consolidation. Neurobiol. Aging 20, 363-372.

Ward, N. L., and Hagg, T. (2000). BDNF is needed for postnatal maturation of basal forebrain and neostriatum cholinergic neurons in vivo. Exp. Neurol. 162, 297-310.

Webster, M. J., Herman, M. M., Kleinman, J. E., and Shannon Weickert, C. (2006). BDNF and trkB mRNA expression in the hippocampus and temporal cortex during the human lifespan. Gene Expr. Patterns 6, 941-951.

West, M. J. (1993). Regionally specific loss of neurons in the aging human hippocampus. Neurobiol. Aging 14, 287-293.

West, M. J. (1999). Stereological methods for estimating the total number of neurons and synapses: issues of precision and bias. TINS 22, 51-61.
West, M. J., Kawas, C. H., Martin, L. J., and Troncoso, J. C. (2000). The CA1 region of the human hippocampus is a hot spot in Alzheimer's disease. Ann. N.Y. Acad. Sci. 908, 255-259.

Ypsilanti, A. R., Girao da Cruz, M. T., Burgess, A., and Aubert, I. (2008). The length of hippocampal cholinergic fibers is reduced in the aging brain. Neurobiol. Aging 29, 1666-1679.

Yuste, R., and Bonhoeffer, T. (2001). Morphological changes in dendritic spines associated with long-term synaptic plasticity. Annu. Rev. Neurosci. 24, 1071-1089.

Zaman, V., Nelson, M. E., Gerhardt, G. A., and Rohrer, B. (2004). Neurodegenerative alterations in the nigrostriatal system of trkB hypomorphic mice. Exp. Neurol. 190, 337-346.

Zhang, Y., Qiu, C., Lindberg, O., Bronge, L., Aspelin, P., Backman, L., Fratiglioni, L., and Wahlund, L. O. (2010). Acceleration of hippocampal atrophy in a non-demented elderly population: the SNAC-K study. Int. Psychogeriatr. 22, 14-25.

Conflict of Interest Statement: The author declares that the manuscript was conducted in the absence of any commercial or financial relationships that could be construed as a potential conflict of interest.

Received: 25 May 2010; paperpending published: 23 June 2010; accepted: 26 July 2010; published online: 13 August 2010.

Citation: von Bohlen und Halbach $O$ (2010) Involvement of BDNF in age dependent alterations in the hippocampus. Front. Ag. Neurosci. 2:36. doi: 10.3389/ fnagi.2010.00036

Copyright (C) 2010 von Bohlen und Halbach. This is an open-access article subject to an exclusive license agreement between the authors and the Frontiers Research Foundation, which permits unrestricted use, distribution, and reproduction in any medium, provided the original authors and source are credited. 